\title{
Technologies, literacies in English oral communication and teacher education: an empirical study at the university level
}

\section{Tecnologias, letramentos em comunicação oral na língua inglesa e a formação do professor: um estudo empírico no contexto universitário}

\author{
Reinildes Dias* \\ Universidade Federal de Minas Gerais \\ Belo Horizonte, Minas Gerais, Brasil. \\ Sônia Maria de Oliveira Pimenta** \\ Universidade Federal de Minas Gerais \\ Belo Horizonte, Minas Gerais, Brasil.
}

\begin{abstract}
The main purpose of this article is to report data findings and results obtained in a 60-hour course designed for 20 pre-service English teachers in the first semester of 2014. The course integrated technologies and pedagogical practices to improve advanced oral communication skills. The theoretical framework comprised Kalantzis and Cope (2012, 2013) and their work on literacy, the use of technology by Prensky (2010) and Warschauer (2011), blended-learning (THORNE, 2003) and genre (KRESS, 2003). The methodology involved critical reflection of teaching practice, blendedlearning classes using Moodle forums and class discussions as well as recording of personal introductions, interviews and documentaries. The results showed that pre-service teachers improved their oral communication skills by means of critical reflection, use of web tools and recording, thus comprehending oral genres in a significant way. Based on our study, we can say that our student teachers will be able to implement these instructional strategies in their future teaching practices.
\end{abstract}

KEYWORDS: advanced oral communication; b-learning; technologies; literacies.

RESUMO: O objetivo deste artigo é relatar os dados e resultados obtidos de um curso de 60 horas elaborado para 20 alunos, futuros professores de inglês em formação inicial, realizado no primeiro semestre de 2014. O curso integrou

\footnotetext{
*reinildes@gmail.com

**soniapimenta1@gmail.com
} 
tecnologias e práticas pedagógicas para aperfeiçoamento das capacidades de comunicação oral dos alunos. O quadro teórico envolveu Kalantzis e Cope (2012, 2013) e seus trabalhos com letramentos, o uso de tecnologias digitais (PRENSKY, 2010; WARSCHAUER, 2011), blended learning (THORNE, 2003) e gênero (KRESS, 2003). A metodologia aproximou as reflexões críticas de práticas pedagógicas, aulas no formato semipresencial utilizando fóruns do Moodle e discussões em aula, assim como gravações de apresentações pessoais, entrevistas e documentários. Os resultados mostraram que professores em formação préserviço melhoraram suas habilidades orais de forma significativa. Com base em nosso estudo, acreditamos que eles serão capazes de implementar essa pedagogia, denominada pedagogia dos letramentos, em suas práticas de ensino quando passarem a atuar em sala de aula.

PALAVRAS-CHAVE: comunicação oral avançada; aprendizagem semipresencial; tecnologias; letramentos.

\section{Introduction}

This paper is about the integration of technologies into our pedagogical practice at a public university in Belo Horizonte (Minas Gerais, Brazil). The pedagogy we designed was geared to pre-service teachers who had to improve their capacities to communicate orally in English and to reflect on how to apply what they had learned and experienced to their later teaching as professional classroom teachers. We decided to design a course toward the development of their oral communication literacies considering the following theoretical frameworks: the educational use of technologies (PRENSKY, 2010; WARSCHAUER, 2011), literacies in today's evolving world (KALANTZIS; COPE, 2013, 2012), multimodality (KRESS, 2003), blended learning (THORNE, 2003), and genre (KRESS, 2003). Our classes were always practice oriented based on these different theoretical perspectives to enrich the reflections of our students, future English teachers, about the interconnections between learning and teaching. They improved their oral communication through the use of some free web tools to comprehend different oral genres and record them digitally. They also reflected about how to transfer what they had learned to their future practice in the context of public schools in Brazil. We used a blended-learning (b-learning) modality of teaching (THORNE, 2003) and had both online classes through the learning management system Moodle and some face-to-face interactions in one of the computer labs of the university. Half the classes were online and half in the lab. In this paper we intend to report this experience that allowed us to bring together some current theories about language, education and practical use in a literacies pedagogy (KALANTZIS; COPE, 2013). First, we will 
briefly review the literature, and then we will present our research context, the participants, and a description of the course we designed to best meet our students' needs and our teaching-learning purposes. We will conclude with a reflection about what we did and with some recommendations for future research on language and education related to oral communication in English. We believe that these recommendations can be integrated to the process of teachers' professional development, which is focused on the new social demands of the present digital age. The research questions that guide us are: "How can we develop a literacies pedagogy oriented to oral communication for future English teachers at the university level?" and "How effective is the use of blended learning (b-learning) as a modality of teaching for the development of literacies in oral communication?"

\section{On technologies}

The pervasiveness of digital technologies in contemporary society is undeniable. We are surrounded by them, and very often we fail to notice how much we use them for entertainment, schooling, public transportation, and bank transactions in everyday situations. Most of today's kids, teenagers, and young adults have become so deeply familiar with them that they sometimes cannot understand how life could be experienced or how to interact with others without them. Children and young people are socially engaged by networking websites such as Facebook and Twitter, and also by apps (mobile applications) they download to their smartphones. Most often, a major part of them can fluently speak the language of technology. But as the digital divide phenomenon takes place locally and globally (WARSCHAUER, 2002, 2011), we have to acknowledge that still a significant portion of today's kids and young adults cannot have access to the wealth of opportunities provided by the virtual interconnectedness of the world.

However, the need to integrate digital technologies with current pedagogy practices for English learners is widely accepted by applied linguists, and various academic investigations have been recommending them, especially for the development of collaborative writing (MURADAS, 2013; SANTOS, 2011; VEADO, 2008 to mention only a few). On the other hand, studies on literacies in oral communication along with digital tools are still rare and some have been flourishing only recently (ANJOSSANTOS; EL KADRI; GAMERO; GIMENEZ, 2013; DIAS, 2011, 2012). The investigations developed by Muradas (2013), Santos (2011) and Veado 
(2008) were based on the view of writing as a collaborative cyclical process with the use of web tools that could afford online interactions among the participants. This process was intertwined by feedback from peers based on drafts and rewritings until the final version was edited and published online. All these studies also included a concern with students learning the basic characteristics of the written texts they were creating to meet their writing social purposes according to the audience they were addressing. A key aspect was the collaboration amongst students that was mediated by web tools such as wikis, blogs and Google Docs. All these studies privileged a wider approach that included not only knowledge construction and competence development in the English language, but also critical engagement. Based on our own teaching experience at Faculdade de Letras (UFMG), we can affirm that collaborative writing tasks with the support of digital technologies are not only valuable for learning to compose, but they are also of considerable importance for learning how to read and about the content material. Furthermore, writing in collaboration with peers develops students' engagement with the virtual world in such a way that they can learn and improve their real use of the English language. Based on our present study and on our experience, the process of developing oral literacies (listening and speaking) of pre-service teachers at the university level has also been profitable due to the learners' positive involvement and learning in our classes during the semester.

In fact, if we listen to today's learners, we have to acknowledge the importance of Prensky's ideas related to his distinction between digital natives and digital immigrants (2001). This inspiring researcher has been continually encouraging educators to use technology in powerful and diversified ways to engage students in real and useful learning for their future. Based on his work, our teaching approach attempted to engage our students by giving them opportunities to assume authorship for what they created orally during speaking, to collaborate with each other and to publish their oral interviews and documentaries to a wider audience. They were given the chance to powerfully use digital tools to develop their listening and speaking capacities (PRENSKY, 2010), to make decisions in collaborative ways, to connect with their colleagues and friends and to share their opinions around the world.

Since the late 1900s and early 2000s, another prestigious educator, Mark Warschauer $(2002,2011)$, has been paving the way for the use of 
technology towards the following goals: to improve academic achievement, including language learning, to facilitate new kinds of 21 st-century learning, and to promote educational and social equity. However, he warns us by saying that digital technologies are not relevant per se. They should be used as tools "to think with" in well designed task-based learning environments that involve students in both "gathering and analyzing information; creatively synthesizing information and solving problems; evaluating and revising results; and sharing, publishing, and/or acting on what was learned" (WARSCHAUER, 2011, p. 10).

Regarding the studies on literacies in oral communication with digital tools, Dias (2011) designed a virtual environment, Portal for the English Teacher, during her post-doctoral studies, based on the theories that underlie this article, particularly on the work developed by Prensky and Warschauer, and also on those that give support to teachers' reflective discussions with colleagues for professional development (DEWEY, 1933; SCHÖN, 1996). Several virtual forums have been designed for this end. This means that teachers in different regions around the world can construct knowledge about teaching and learning collaboratively with each other. They can also contact the portal designer through the available online forums and email addresses. The portal presents, discusses, encourages reflections and exemplifies the use of some web tools for the development of English teachers' oral communication and subsequent application with their students. Some of these tools are: Voki, MailVU, Audacity, online videos, and websites for pronunciation, for example.

In a 2012 article, Dias recommends a genre-based educational use of podcasts about different topics for the development of oral communication in English. One of the key aspects in her proposal is a cyclical collaborative interactions for the improvement of participants' oral communication (listening and speaking), which includes stages of recorded rough drafts, a first version, revisions, a second version, until the last one is published as an audio digital file on host sites such as PodOmatic, Podbean, or SoundCloud. In Module 2 of their textbook for language and teacher education, AnjosSantos, El Kadri, Gamero, and Gimenez (2013) explore the discursive and linguistic-discursive characteristics of podcasts and their social-cultural contexts to recommend their use for the consumption and production of meanings in the English language in digital times. They designed reflective learning tasks underpinned by the genre approach pedagogy. 
They particularly focused on the human and communicative actions through language practices by the use of podcasts regarding critical reflections on the "student-teacher-knowledge triad" (ANJOS-SANTOS; EL KADRI; GAMERO; GIMENEZ, 2013, p. 57).

Overall, the affordances of the present web tools have been changing the landscape of digital learning, knowledge construction, and collaboration amongst learners for educational purposes. Results of technology-based teaching added to core academic subjects, including those from our study about oral communication in English, are more related to learners' successful achievements and higher levels of interest and satisfaction with the learning situation. The web tools, viewed from the perspective of a "participatory web" whose features enhance creativity and collaboration amongst users, can be used to encourage learners' participation, creation, and sharing of what they produce in the process of constructing knowledge in English. Learners can go beyond the passive role of simply absorbing information from books and teachers' classes without critical thinking and collaboration with peers to actively participate in significant web learning tasks. Moreover, they can immerse in the culture of English-speaking countries via the Internet, thus consuming and producing meaning in a more meaningful way. Additionally, learners have the opportunity to interact in English more often through listening and speaking in order to broaden their language oral competence in collaboration with other speakers of this language, thus assuming an agentive role in learning situations that expose them to real oral interactions.

\section{On multiliteracies}

The impact of technologies on language, society, and communication in digital times influenced a group of international scholars, the New London Group, to challenge traditional pedagogical practices to propose a "pedagogy of multiliteracies" (COPE; KALANTZIS, 2000). Recently, Kalantzis and Cope (2012, p. 4) have referred to literacies as an educational view that is geared "to catch the flavour of a more contemporary, relevant and inclusive approach to knowledge". As the two researchers remark, this pedagogy "attempts to explain what still matters in traditional approaches to reading and writing, and to supplement this with knowledge of what is new and distinctive about the ways in which people make meanings in the contemporary communications environment" (KALANTZIS; COPE, 2012, p.1). From their point of view, a literacies pedagogy accounts for 
two important aspects of education, namely, today's social and cultural diversities, including language varieties and dialects, and the multiple ways of meaning making via different modes of representation in today's digital communication landscape. The first aspect of this pedagogy refers more specifically to "the variability of conventions of meaning in different cultural, social or domain-specific situations" (KALANTZIS; COPE, 2013, p.1). In everyday communication we "move between different social spaces [e.g., school, home, theater, restaurant, soccer field, etc.] [using] different social languages [formal, respectful, informal, for example]". Being aware of these differences in social spaces and using adequate language patterns become a fundamental issue in educational settings in digital times. As Kalantzis and Cope (2012, p. 1) explain, " $[t]$ he logic of multiliteracies recognizes that meaning making is an active, transformative process, and a pedagogy based on that recognition is more likely to open up viable life courses for a world of change and diversity". They also remark that "the sociolinguistic conditions of our everyday lives increasingly require that we develop a capacity to move between one social setting and another where the conventions of communication may be very different" (KALANTZIS; COPE, 2013, p.1).

Furthermore, a literacies pedagogy includes the development of learners' awareness of their crucial role in acting and transforming local and global social settings (FREIRE, [1974] 2005). Therefore, it is expected that learners assume an active participation as conscious citizens toward social, cultural and economic problems to reflect, debate, and act upon them. Instead of reproducing social inequalities, this pedagogy aims at engaging learners and future teachers in the process of developing "social and civic responsibilities, commitment to promoting the common good, and participation in democratic processes and cultural diversity" (CUMMINGPOTVIN, 2009, p. 84). This means to stand up for social justice and a just world actively participating as conscious citizens to fight for the rights of others. A literacies pedagogy is thus of vital importance "for active citizenship, centred on literate learners as agents in their own knowledge processes and capable of contributing their own ideas as well as negotiating the differences between one community and the next" (KALANTZIS; COPE, 2012, p. 52).

The second aspect of literacies in teacher education to meet learners' needs is also related to the recognition of the worldwide influence of digital technologies and their impact on the current communication settings. This 
is highlighted by a key feature of oral and written texts: multimodality. Meaning in today's society is made with multimodal representations that include written, oral, visual, tactile, spatial, audio, and gestural modes of communication. The affordances of digital technologies allow us to consume/produce texts that are increasingly multimodal. This has a crucial impact on the need to extend the range of literacies beyond alphabetical modes of representations to include typical current multimodal codes. As social forces define the nature of literacy, "written modes of [communication are presently being] complemented by, or replaced by, other ways of crossing time and distance, such as recordings and transmissions of other patterns [...] of meaning" (KALANTZIS; COPE, 2012, p. 52).

Multimodality (KRESS, 2003) is a relatively new field of inquiry that systematically addresses issues regarding changes in society, especially those in relation to new media and technologies. At its core is a deep concern with the human communication landscape that has been dramatically changing by the affordances of the current digital tools of the media age. Kress (2003) acknowledges the existence of two related factors in this scenario: "the broad move from the now centuries-long dominance of writing to the new dominance of the image and $[\ldots]$ the move from the dominance of the book to the dominance of the medium of the screen." (KRESS, 2003). He goes on by predicting that the combined effects of these two factors will have profound effects on human, cognitive/affective, cultural and bodily engagement with the world, and on the forms and shapes of knowledge (KRESS, 2003). He also envisions that the effects of these two changes in combination will have the widest imaginable political, economic, social, cultural, conceptual/cognitive and epistemological consequences. One of them is the need to move from the notion of literacy toward literacies in teacher education if we want to account for today's multiple modes of meaning making. Writing and speech together with images, sounds, gestures, and space refer to the different sets of semiotic resources that are socially and culturally shaped (PIMENTA; SANTANNA, 2007). Any combination of these modes serves the producer's specific purposes for making meaning in a specific act of communication, oral or written. Such combinations do not follow a fixed set of rules but have to accomplish social and cultural meaning in every single instantiation. As pointed out in the Glossary of Multimodal Terms (2012), multimodality is underpinned by three interconnected assumptions:

[It] assumes that representation and communication always draw on a multiplicity of modes, all of which contribute to meaning. [...] 
[It also] assumes that resources are socially shaped over time to become meaning making resources that articulate the (social, individual/affective) meanings demanded by the requirements of different communities. [...]

[...] [A]ll communicational acts are shaped by the norms and rules operating at the moment of sign making, and influenced by the motivations and interests of [speakers/ writers] in a specific social context. (GLOSSARY, 2012).

\section{Blended learning}

Blended learning (b-learning) is a learning approach that combines face-to-face classes with distance online meetings. We adopted this teaching modality because it could give us the opportunity to blend traditional classroom experiences with distance education strategies to meet the needs of a literacies pedagogy for oral communication in English. Our major aim was to give students time and privacy to develop their listening and speaking capacities. Based on our teaching experience, we have been observing that there are students who are reluctant to speak in traditional classrooms. We decided then to experiment with a b-learning approach so as to give them the opportunity to record their voices quietly at home, listen to what they had recorded, get feedback from peers and then record again. This way they could make mistakes without the constraints of peers' presence in the classroom, learn from their mispronunciations and speak more appropriately.

As acknowledged by Thorne (2003, p. 16), b-learning "represents an opportunity to integrate the innovative and technological advances offered by [free web tools, for example] with the interaction and participation offered in the best of traditional learning". Furthermore, this researcher mentions the following advantages in relation to this teaching approach: it enhances collaboration, it is a truly flexible strategy, it can provide the right learning at the right time and in the right place; it can be universal and cross global boundaries; it can bring students together through different cultures and time zones, without neglecting the importance of face-to-face interactions. All of this speaks to the impact that this strategy could have on our own teaching environment at the university level. 
It is important to remark that the communication digital technologies in the new media age and the existence of effective learning management systems such as Moodle have led to the proliferation of online learning at higher education in various countries of the world. Universidade Aberta Brasileira (UAB - Open University of Brazil) $)^{1}$, created in 2005, is one of them. It focuses on distance learning as one of the "means of providing opportunities for those who do not otherwise have access to education in their own communities" (BRASIL, 2005). UAB is one of the most successful online learning programs for teacher education in Brazil, coordinated by the Ministry of Education and Culture (MEC).

\section{Research investigation}

\subsection{The context}

Our investigation took place in the first semester of 2014 with two classes of students, one in the morning and the other in the evening, at a public university in Belo Horizonte, Minas Gerais. We had 20 pre-service teachers enrolled in a teacher education course for the development of literacies in English oral communication. Each course was 60 hours long and worth 4 credits. The research questions that guided us were: How can we develop a literacies pedagogy oriented to oral communication for future English teachers at the university level? How effective is the use of blended learning as a modality of teaching for the development of literacies in oral communication?

\subsection{Course description}

LET-261: Oral expression: Advanced studies (optional). Content: Characteristics of oral discourse: theoretical and practical aspects. Some oral genres and how they are realized in speaking and in debates. Listening strategies. Some web tools for recording texts. Peers' collaboration during the online and lab meetings. Recorded personal introductions, interviews, and documentaries. Teaching modality: b-learning. Prerequisite: LET-060: Oral expression (mandatory)

\footnotetext{
${ }^{1}$ More information at http://uab.capes.gov.br/index.php
} 


\subsection{Teaching modality}

We chose the blended modality (b-learning) based on what we learned about it through our research studies and on our own experience in previous courses we have taught. Our university had the necessary equipment for our lab meetings and the students had their own computers for the online classes, during which they recorded their work. Our mix of different web tools for the distance meetings included: the voice mail, MailVU; the virtual space for creating speaking avatars, Voki; the recording resource, Audacity; and a plug-in to change the audio recording into an mp3 file. Also included were tools students could use to check their pronunciation: common online dictionaries, online pronunciation guides, pronunciation of single words, and sites for learning pronunciation ${ }^{3}$. Additionally, sites for listening activities, YouTube videos, TED videos, and movie trailers were part of our repertoire of b-learning strategies.

\subsection{Changing practices}

We followed the two aspects of a literacies pedagogy as discussed above. We also included the notion of text consumption/production in oral communication as social practices. Our changing literacy landscape included readings, debates, and reflections about oral discourse and communication at the advanced level. It also encompassed notions of digital learning, its relevance in the new media age, and the use of digital tools for designing and recording oral texts in different genres. The recording web tools used by students were Voki and Audacity. They shared what they did with peers and friends through $\mathrm{mp} 3$ files that were either uploaded to Moodle or sent by email. We believe that sharing by the process of publishing online is of crucial relevance in learning meaningfully. This gives learners the sense of authorship as they become meaning makers and not simple replicators of representational conventions. Learners also feel they are interacting with a real audience and not only working to accomplish the goals of a course, get marks, and be approved at the end of the semester. We also believe that

\footnotetext{
${ }^{2}$ www.mailvu.com, www.voki.com, and http://audacity.sourceforge.net/. ${ }^{3}$ http://www.merriam-webster.com/help/pronguide_intro.htm, http://www.howjsay. com, http://cambridgeenglishonline.com/Phonetics_Focus/\# and http://www.uiowa. $\mathrm{edu} / \sim \operatorname{acadtech} /$ phonetics.
} 
they "become knowledge producers, drawing together a range of available [...] resources, instead of being knowledge consumers fed from just one source [the textbook]" (KALANTZIS; COPE, 2012, p. 11), that is, they applied knowledge creatively. Our changing practice followed the pattern of "knowledge processes" suggested by Kalantzis and Cope: experiencing, conceptualizing, analyzing, and applying (Fig. 1).

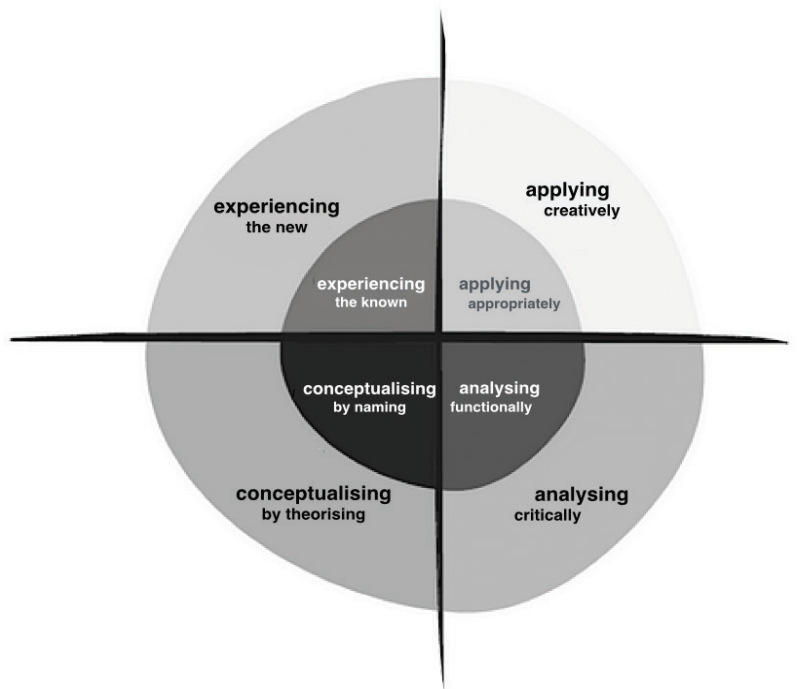

FIGURE 1 - Knowledge processes (KALANTZIS; COPE, 2013)

Experiencing the known engages learners in reflecting about what they already know so as to connect their old knowledge, related to their cultural backgrounds, identities and interests, to new situations, information, and ideas. Learning is more effective when it is socially situated, when it connects with learner identities, and when it is meaningful to them. A literacies pedagogy starts where the learner is at (KALANTZIS; COPE, 2012; 2013).

Conceptualizing "entails drawing distinctions of similarity and difference, categorising and naming the constituent elements of the thing to which the concept refers" (KALANTZIS; COPE, 2013). We encouraged our students to conceptualize three important constructs in our teaching approach described in this article: literacies, multimodality, and genre.

Analyzing functionally involves learners' explanation of "the ways in which texts work to convey meaning, the way their design elements function to create a whole, meaningful representation. In the process of analyzing 
critically, learners question the interests behind a meaning or an action (KALANTZIS; COPE, 2013). They learn that texts are never neutral and that they convey ideologies that have to be questioned to be accepted or rejected.

Applying appropriately entails the application of knowledge and understandings in predictable or "correct" ways. Applying creatively, on the other hand, is a process of making the world anew with fresh forms of action and perception (KALANTZIS; COPE, 2013). Our students applied creatively what they learned when they created their own documentaries, recorded them and shared them with others via mp3 files.

\subsection{Data gathering}

Data was gathered through the oral tasks done by our future English teachers during our course. For the purposes of this article, we are going to discuss the data gathered from the following tasks: a. watching and analyzing a video by Mr. Bean, "The devil Toby welcomes you to hell"4; and b. designing and creating an audio documentary about English varieties in the world.

\subsection{Data presentation and analysis: Mr. Bean's video}

Based on our course description and following Kalantzis and Cope's (2013) knowledge processes, we designed the following phases for the development of our students' oral literacies:

\subsubsection{Experiencing}

First, we briefly discussed the term "multimodality" and elicited information from our students to complete a definition of the term. With our support, they also listed some of the meaning-making modes in written and oral genres. We then asked them to watch Mr. Bean's video and list the different modes of representation they could notice in it. The main purpose of this phase was to weave practical out-of-school experiences, that is, experiencing the known to establish connections with the new in the process of learning (KALANTZIS; COPE, 2013). This means that based on our students' daily interactions with multimodal texts in real situations of communication (what they already knew), we discussed the aspects of multimodality in the video and they listed them.

${ }^{4}$ Available at https://www.youtube.com/watch?v=2ETCM90yHiY. 
Our analyses, based on their recorded comments and transcribed here, revealed that our students could list almost all the modes, namely, "sounds, spatial organization of the scene, Mr. Bean's purple robe, colors, lighting, smoke". They also noticed "the purposes of the modes in meaning making: screams of terror to represent pain; the top to bottom movement as $\mathrm{Mr}$. Bean steps down the stairs to address his audience, meaning that he is more powerful than his addressees; his outfit (purple robe and a pair of horns) to characterize his persona, the devil". We claim, and so does Kress (2003), that meanings in different modes are culturally and socially made. Our students could also point out the nuances of the oral discourse in Mr. Bean's speech: "intonation, repetition of words, word puns, body language." We believe our students could construct meaning because they "experienced as known" the idea of hell as a place for punishment. Another point is that our students live in a multimodal world where representations are made meaningful by the use of different semiotic codes they can recognize and interpret. Their comments reveal that "experiencing the known" engaged them in comprehending the language resources used in the video in a meaningful way.

\subsubsection{Conceptualizing}

In this phase, students read about these constructs: literacies (KALANTZIS; COPE, 2013; 2012); multimodality (KRESS, 2003), and genre (KRESS, 2003), besides some of our publications (DIAS, 2012; PIMENTA; MAIA, 2014). We held debates about them and the students also summarized what they read. Additionally, we discussed the concept of hell that most of us hold in the Western culture. One of the questions that guided us was: "Is hell a religious concept or a cultural one?" Our analyses showed that the students constructed knowledge about the key concepts collaboratively. What was novelty for them became known. Learners became active conceptualizers for having participated in the process of meaning making. As far as the idea of hell is concerned, there was no consensus. Some positioned on the religious side of the issue and others on the cultural one.

\subsubsection{Analyzing}

As learning entails the processes of analyzing functionally and creatively, we encouraged our students to assume a critical position regarding the purposes of Mr. Bean's message and his role as a comedian. We asked these questions: "Why was this video made? For what purposes? Can you tell 
that it is a successful video? Why? Are comedians allowed to play with any human beliefs in their jokes? Why do they choose cultural as well as current issues to make fun of?"

Our analyses revealed that our students could understand that Mr. Bean "played his comedian role well and chose a cultural theme we consciously or unconsciously fear - we learned about it in our interactions in the community we live in and through all its representation in movies, songs, religious beliefs." Our students also grasped the main purpose of a joke - "to make people laugh". Consensual was the idea that Mr. Bean accomplished his goal in an outstanding way. They also mentioned "sarcasm, irony, and humor" as key elements of jokes. They also realized that "cultural and current issues shared by a comedian and his/her listeners are the main ingredients of a good joke". However, some students disagreed with the theme chosen by the comedian because of their religious beliefs. All the students' comments were recorded and posted as mp3 files on one of our Moodle forums. One of them posted this message:

In all the recorded files we had to do, we had a lot of thing to learn and some of them were a challenge to me, but it was very interesting and useful. Some of them took me hours to do, but I did it!!! To me the whole semester was useful. All the work taught so much about learning and technology. (Anonymous)

\subsubsection{Applying}

As our groups of learners are getting prepared to become classroom teachers, we asked them to create a lesson plan for the use of this video with their future students, that is, they applied creatively what we discussed in class. Our analyses of their lesson plans revealed that they understood the purposes of a literacies pedagogy and the vital role of genres to prepare learners for facing the challenges of the real world regarding making meaning of multimodal genres. They also understood the importance of supporting learners to become aware of their role in the process of social change. We believe that both aspects of a literacies pedagogy were fully understood by our future English teachers. We presume that what they learned in our course will be integrated into their future teaching, as shown by their answers (Fig. 2). 


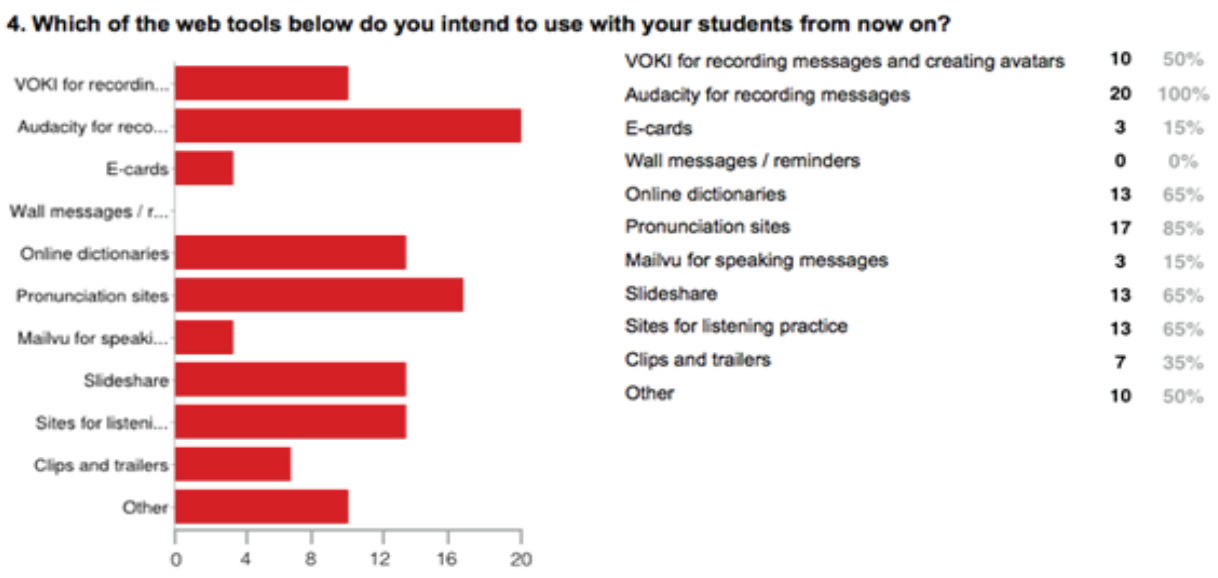

FIGURE 2 - Students' answers

\section{Data presentation and analysis: an audio documentary}

Our students also created an audio documentary about English varieties in the world. Also based on our course description and following Kalantzis and Cope's (2013) pattern, we designed the following phases for the development of their work related to their oral literacies: experiencing, conceptualizing, analyzing, and applying.

\subsection{Experiencing}

As the main purpose of this phase is to weave practical real language experiences and school learning (KALANTZIS; COPE, 2012; 2013), we asked our practice teachers to tell us what an audio documentary is, based on what they already knew about this genre. We started with what they already knew to advance to the new situation of creating a documentary of their own. They were also encouraged to give examples of audio documentaries they had already heard. We also asked them to google the term for further information. Additionally, they listened to Malala Yousafzai's speech at the United Nations Youth Assembly to account for social differences around the world, one of the key aspects of a literacies pedagogy.

Our analyses, based on their recorded comments, revealed that our students already knew a lot about audio documentaries though they watch video documentaries more often. Most of them mentioned YouTube documentaries. All of them had already taken literature courses and were able to mention some of the generic characteristics of documentaries from 
a literature point of view. We also discussed the main representational ways used in audio multimodal documentaries that are expressed in different modes: the sounds of both the recorded voice and the background track, and the distinctive attributes of oral discourse, namely, "intonation, tone of voice, stress, rhythm, syntactic parallelism". Also relevant are "the formal speech-like language in documentaries, the use of expository and narrative prose, and the features of involvement with the audience".

As our practice teachers had to create an audio documentary about the many varieties of the English language in the world, we also held a debate on this issue. Our main purpose was to grasp how much they knew about this topic. We also debated about language and social discrimination to learn how much they knew about one important aspect of a literacies pedagogy: the respect for diversity and the acknowledgment of its prevailing presence in a globalized digital world.

Our analyses revealed that they were aware of the English varieties, especially the differences between American and British English. However, they told us they had never heard anything in the other varieties of the language. They showed interest in learning some of their peculiarities. We noticed that they had not yet given much thought about world's diversities in social, economical, and cultural domains. They realized the importance of a respectful position in relation to them. The speech by Malala Yousafzai was a productive source for the debate on diversities: "her variety of English, the respectful way she greeted her audience, her deep respect for God, her clothing, the prejudice against women she and others face in her country". Our students experienced the known related to their cultural backgrounds and identities during our in-class discussions to get connected to the new information they had acquired at the end of this phase.

\subsection{Conceptualizing}

In this phase, the students reviewed knowledge on these constructs: literacies, multimodality, and genre. Additionally, they defined the term "documentary" in more detail and searched information on some $\operatorname{sites}^{5}$ to support them in how to create an audio documentary. For

${ }^{5}$ https://www.udemy.com/blog/how-to-make-a-documentary/, http://www.desktop-documentaries.com/making-documentaries.html, and 
guiding the debate, we provided the following questions: "How do you define the term documentary? How have digital technologies shaped/ reshaped the production and distribution of documentaries? What is the role of documentaries in social change/movements? How have new digital technologies affected the production/distribution/reception of documentaries around the world?"

Our analyses made us understand that our practice teachers were able to grasp the communicative purpose of documentaries and their main generic characteristics. They could also understand them as "common social practices in the contemporary world". They could link the creation of documentaries to some digital recording tools such as Audacity. They also realized the importance of multiple modes of representation in the process of producing a documentary during the discussions that were held in this phase. Additionally, they understood that "documentaries can be one of the multimodal genres in a literacies pedagogy to prepare learners for consumption and production of multiple modes of meaning, and for getting prepared for citizenship in a diversified sociocultural society". What they already knew about documentaries became critical knowledge of this genre for them.

Regarding the issue varieties of the English language, we asked our students to watch two videos by David Crystal $(2012 ; 2010)$ in order to fully understand why changes occur and how they continue indefinitely. This way, they were experiencing the new so as to learn from what they heard. These were the videos we recommended: "Academic English" and "How is the Internet changing the language?". Our analyses revealed our students' striking interest on the issue and this helped us encourage them to produce their documentaries about it. The debate we held was fruitful and motivated them to research on the topic for the production of their own audio documentaries.

\subsection{Analyzing}

This phase involved analyses of the communicative functions of audio documentaries, their multimodal design and critical interrogation of the interests of participants in the digital communication process by our future English teachers. We provided them with some sites ${ }^{6}$ whose main purpose

http://mediaeducationlab.com/essential-question-1-what-documentary.

"'Hearing the Documents" (http://realityradiobook.org/hearing-the-documentaries), "The 
is to post audio files for free. We asked them to analyze the documentaries to fully understand their generic characteristics and their social functions in the contemporary world. Our analyses showed that our students could list the multimodal aspects of audio documentaries and state their main social functions or communicative purposes. They were able to relate the questions we asked to examples taken from the audio documentaries they heard. This way, they analyzed the documentaries so as to understand the ways in which they work to create meaning.

This phase also involved the development of students' awareness of some of the English varieties. They were encouraged to visit some news sites from Jamaica, Australia, Belize, and Canada. They were also asked to orally report on what they found out and share their findings with us on one of our Moodle forums. Our analyses revealed that the practice teachers were very excited about what they found out regarding varieties of the English language. In their recorded reports, they exemplified some peculiar uses of some words and more specifically on the pronunciation of words and the different rhythms in the different varieties.

\subsection{Applying}

As this phase "entails the application of knowledge" constructed previously, we asked our future English teachers to design documentaries about varieties of English in order to put what they learned "in communicative action" (KALANTZIS; COPE, 2012, p. 56). Each group of two students chose one variety. They researched about the English-speaking countries and their varieties of the language. Together we selected the keywords for their work: the country, capital city, cultural aspects; cuisine; peculiarities in the English language. They applied knowledge about the main issue of their documentaries as well as on how to create them. For recording their work, they used the software Audacity, a free web tool. They were asked to create a script, discuss it with their peers, rewrite it and make changes, record the documentary, exchange the audio with peers, correct the inadequacies if any, and finally edit it. We also participated in their process of creating their documentaries. They used Audacity's editing resources to remove

Documentary" (http://www.bbc.co.uk/programmes/p00fvhsf), "360documentaries" (http://www.abc.net.au/radionational/programs/360/), and "Talking History" (http:// www.talkinghistory.org/). 
noises in the background and to add effects and sound tracks. Our students not only applied knowledge and understandings in a "correct" way but also applied what they learned creatively in the process of producing their own documentaries. Our analyses revealed that they could develop effective audio documentaries about English varieties.

From experiencing to applying creatively. They created documentaries on American English (http://goo.gl/A6ryoo), Australian English (https:// vimeo.com/117136441), English dialect (http://goo.gl/LFNg1D), Irish English (http://goo.gl/CtqRAB), and Jamaican English (http://goo.gl/ $\mathrm{R} 40 \mathrm{f1O}$ ). We can say that our students went through a dynamic process of knowledge transformation as they were able to incorporate the available meaning-making web resources into their work. Additionally, they transferred knowledge, competence, and oral literacies to a new context of practice. The final product gave evidence of their involvement in the task, their participatory roles and their empowerment concerning the use of different modes in their documentaries as well as their appreciation of cultural and linguistic diversities. Celebrating and responding to diversity have become essential for teacher education in the new millennium, which is characterized by shifting local and global settings. We also noticed that our future teachers improved their oral literacies in the process of making meaning through what they produced collaboratively with peers. This is another message from one of our students:

I had a great opportunity to learn much more about Audacity than I deemed to know. The tasks were really challenging because I had to learn how to operate new tools while producing our own materials. As an individual/citizen it's good to have the chance to produce and give your own point of view instead of just reading and interpreting other people's work, as occurs in almost all the other subjects. Besides, apart from the first project, all the others involved collaborative work - which is a very important skill in the contemporary labor market. (Anonymous)

\section{Final remarks}

Based on the research we developed on the two aspects of literacies and on the notion of genre as a sociocultural artifact, we designed a course which involved four knowledge processes, "experiencing, conceptualizing, analyzing, and applying” (KALANTZIS; COPE, 2013), in order to answer 
our first research question: "How can we develop a literacies pedagogy oriented to oral communication for future English teachers at the university level?". We transformed our pedagogical practice into a meaningful endeavor for the development of our students' literacies in oral communication. We attempted not to be mere replicators of what already existed but tried to bring innovation, creativity and novelty in the development of oral expression in English at the university level. Our focus was on students who were willing to actively participate and be problem solvers and who were challenged to take risks and be innovative. The truth is that our students created good exemplars of oral genres beyond our expectations and were comfortable in providing recorded feedback to each other in the oral format using Voki or Audacity. They learned how to learn through social interactions.

Concerning the second question, "How effective is the use of blended learning as a modality of teaching for the development of literacies in oral communication?", it is possible to say that this modality is very effective and suitable for the digital age. Some of the reasons are: it extended classes beyond the limits of the computer lab; it provided extra time for the tasks so that students could record, record again, check pronunciation, consult with peers, and design the final version; it made learning a flexible process; it enhanced digital learning; it perfectly fitted a literacies pedagogy oriented to oral communication; it provided learners with opportunities to use social media to learn collaboratively with others. Learning was constructed and negotiated actively through social experiences. In short, b-learning can involve learners in the process of ubiquitous learning by the use of web social media and it is fit for the uncertain and unpredictable future of the present era. As there is not yet much research on a literacies pedagogy for the development of oral expression in English and the use of web tools, we hope this paper can encourage reflections and pedagogical actions for politicized teacher education at the university level. We call for a re-conceptualization of our teaching and sustainable innovation to give birth to a critical, engaging, and socially-based literacies pedagogy. This is essential in the process of moving beyond current technical models of teacher education based on artificial debates and role plays. We recommend this path of action for the English teaching/learning settings worldwide, and so does one of our students: "I am going to use these tools as much as possible, so thank you for the great semester." 


\section{References}

ANJOS-SANTOS, L. M. dos; EL KADRI, M. S.; GAMERO, R.; GIMENEZ, T. N. Teaching and learning English in digital times. Londrina: Kan Editora, 2013. BRASIL. Open University of Brazil. Available at:

<http://www.virtualcampuses.eu/index.php/Open_University_of_Brazil >. Retrieved January 18, 2015.

COPE, B.; KALANTZIS, M. (Eds.). Multiliteracies. New York: Routledge, 2000. CRYSTAL, D. How is the internet changing language today? 2010. Available at: $<$ https://www.youtube.com/watch?v=P2XVdDSJHqY>. Retrieved August 23, 2014.

CRYSTAL, D. Academic English: standard vs. non-standard English. 2012. Available at: <https://www.youtube.com/watch? $v=h G g-2 M Q V R e Q>$. Retrieved August 23, 2014.

CUMMING-POTVIN, W. Social Justice, pedagogy and multiliteracies: developing communities of practice for teacher. Australian Journal of Teacher Education, v. 34, p. 81-99, June 2009.

DEWEY, J. How we think: A restatement of the relation of reflective thinking to the educative process. Boston: DC Heath and Company, 1933.

DIAS, R. Portal for the English Teacher. 2011. Available at: <http://goo.gl/PQcqs4>. Retrieved August 26, 2014.

DIAS, R. Gêneros digitais e multimodalidade: oportunidades on-line para a escrita e a produção oral em inglês no contexto da educação básica. In: DIAS, R; DELL'ISOLA, R. L. P. (Org.). Gêneros textuais: teoria e prática de ensino em LE. Campinas: Mercado das Letras, 2012. p. 295-315.

FREIRE, P. Education for Critical Consciousness. London: Continuum, [1974] 2005 (Reprinted).

GLOSSARY OF MULTIMODAL TERMS. Desenvolvido por MODE, 2012. Available at: <www.multimodalityglossary.wordpress.com>. Retrieved July 13, 2013. KALANTZIS, M.; COPE, B. Literacies. Australia: Cambridge University Press, 2012.

KALANTZIS, M.; COPE, B. Multiliteracies in Education. In: CHAPELLE, C. A. The Encyclopedia of Applied Linguistics. Oxford: Blackwell Publishing, 2013.

KRESS, G. Literacy in the New Media Age. London \& New York: Routledge, 2003. MURADAS, P. M. A escrita em inglês do gênero "biodata" por meio de colaboração online em turmas numerosas do ensino médio: um estudo de caso. 2013. $158 \mathrm{f}$. Dissertação (Mestrado em Estudos Linguísticos)-Universidade Federal de Minas Gerais, Belo Horizonte, 2013. 
PIMENTA, S. M. de O.; MAIA, D. G. Multimodalidade e letramento: análise da propaganda Carrossel. Desenredo, v. 10, p. 12-20, 2014.

PIMENTA, S. M. de O.; SANTANNA, C. Semiótica Social e Multimodalidade: o estado da arte. In: MATTE, A. C. F. (Org.). Lingua(gem), Texto, Discurso: entre a reflexão e a prática. Rio de Janeiro: Lucerna, 2007. v. 2, p. 152-174.

PRENSKY, M. Digital natives, digital immigrants. On the horizon, v. 9, n. 5 , Oct. 2001. Available at: <http://www.twitchspeed.com/site/Prensky\%20-\%20 Digital\%20Natives,\%20Digital\%20Immigrants\%20-\%20Part1.htm>. Retrieved July 29, 2014.

PRENSKY, M. Teaching digital natives: partnering for real learning. Thousand Oaks: Corwin, 2010.

SANTOS, V. Wikis na produção textual colaborativa de noticias online em inglês como L2 no meio virtual: um estudo de caso. 2011. 223f. Dissertação (Mestrado em Estudos Linguísticos)-Universidade Federal de Minas Gerais, Belo Horizonte, 2011.

SCHÖN, D. A. Educating the reflective practitioner. San Francisco: Jossey-Bass, 1996.

THORNE, K. Blended Learning: how to integrate online and traditional learning. London: Kogan Page, 2003.

VEADO, M. C. M. Colaboração no processo de produção textual em uma atividade online: um estudo de caso com o gênero resenha de filme. 2008. 194f. Dissertação (Mestrado em Estudos Linguísticos)-Universidade Federal de Minas Gerais, Belo Horizonte, 2008.

WARSCHAUER, M. Learning in the cloud: how (and why) to transform schools with digital media. New York: Teachers College Press, 2011.

WARSCHAUER, M. Reconceptualizing the digital divide. First Monday, v. 7 , n. 7, July 2002. Available at: <http://firstmonday.org/ojs/index.php/fm/article/ view/967/888.\#w4>. Retrieved May 27, 2014.

YOUSAFZAI, Malala. Speech at the United Nations Youth Assembly. 2013.

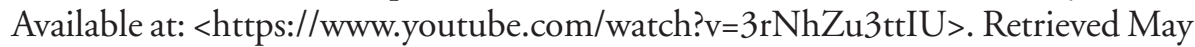
$13,2014$.

Data de submissão: 14/10/2014. Data de aprovação: 12/02/2015. 
